\title{
Anaerobic oxidation of methane in coastal sediment from Guishan Island (Pearl River Estuary), South China Sea
}

\author{
Zijun Wu ${ }^{1,2, *}$, Huaiyang Zhou ${ }^{1}$, Xiaotong Peng ${ }^{1}$, \\ NAN JiA ${ }^{2}$, YUHONG WANG ${ }^{3}$ and LinXi YUAN ${ }^{2}$ \\ ${ }^{1}$ State Key Laboratory of Marine Geology, Tongji University, Shanghai 200 092, China. \\ ${ }^{2}$ Institute of Polar Environment, University of Science and Technology of China, Hefei, Anhui 230 026, China. \\ ${ }^{3}$ National Institute of Health, Bethesda, Maryland 20892, USA. \\ *e-mail: wuzj@tongji.edu.cn
}

The concentrations of $\mathrm{CH}_{4}, \mathrm{SO}_{4}^{2-}, \Sigma \mathrm{CO}_{2}$ and the carbon isotope compositions of $\Sigma \mathrm{CO}_{2}$ and $\mathrm{CH}_{4}$ in the pore-water of the GS sedimentary core collected from Guishan Island (Pearl River Estuary), South China Sea, were determined. The methane concentration in the pore-water shows dramatic changes and sulfate concentration gradients are linear at the base of the sulfate reduction zone for the station. The carbon isotope of methane becomes heavier at the sulfate-methane transition (SMT) likely because of the Raleigh distillation effect; ${ }^{12} \mathrm{CH}_{4}$ was oxidized faster than ${ }^{13} \mathrm{CH}_{4}$, and this caused the enrichment of residual methane $\delta^{13} \mathrm{C}$ and $\delta^{13} \mathrm{C}-\Sigma \mathrm{CO}_{2}$ minimum. The geochemical profiles of the pore-water support the existence of anaerobic oxidation of methane (AOM), which is mainly controlled by the quality and quantity of the sedimentary organic matter. As inferred from the index of $\delta^{13} \mathrm{C}-\mathrm{TOC}$ value and TOC/TN ratio, the organic matter is a mix of mainly refractory terrestrial component plus some labile alga marine-derived in the study area. A large amount of labile organic matter (mainly labile alga marine-derived) is consumed via the process of sedimentary organic matter diagenesis, and this reduces the amount of labile organic matter incorporated into the base of the sulfate reduction zone. Due to the scarcity of labile organic matter, the sulfate will in turn be consumed by its reaction with methane and therefore AOM takes place. Based on a diffussion model, the portion of pore-water sulfate reduction via $\mathrm{AOM}$ is $58.6 \%$, and the percentage of $\Sigma \mathrm{CO}_{2}$ in the pore-water derived from AOM is $41.4 \%$. Thus, AOM plays an important role in the carbon and sulfur cycling in the marine sediments of Pearl River Estuary.

\section{Introduction}

Methane $\left(\mathrm{CH}_{4}\right)$ is considered as the most potent greenhouse gas, and it contributes about $22 \%$ of the climate forcing by all long-lived greenhouse gases in the past 150 years (Lelieveld et al 1998). The $\mathrm{CH}_{4}$ concentration in the atmosphere has more than doubled in the post-industrial era, and an increasing amount of attention has been paid to the production and fate of $\mathrm{CH}_{4}$ in different environments. In marine sediments, sulfate-reducing bacteria outcompete mathanogenic bacteria for available electron donors such as acetate, $\mathrm{H}_{2}$ and low-molecular weight organic matter (Froelich et al 1979; Burns 1998). Once sulfate is removed from pore fluids, methanogenesis begins and results in high concentrations of dissolved $\mathrm{CH}_{4}$ at relatively shallow depths for organic-rich coastal sediments (e.g., Martens and Berner 1977; Martens et al 1998, 1999). After diffusing into overlying sediment, most of $\mathrm{CH}_{4}$ is reoxidized to $\mathrm{CO}_{2}$ using $\mathrm{SO}_{4}^{2-}$ as the terminal electron acceptor, resulting in a zone of coupled sulfate reduction-methane oxidation near the base of the sulfate reduction

Keywords. Anaerobic oxidation of methane (AOM); sulfate reduction; pore-water; South China Sea. 
zone (Martens and Berner 1977; Reeburgh 1980; Moore et al 2004; Treude et al 2005). This process mentioned above is called anaerobic oxidation of methane (AOM), it occurs through the net reaction $\mathrm{CH}_{4}+\mathrm{SO}_{4}^{2-} \rightarrow \mathrm{HCO}_{3}^{-}+\mathrm{HS}^{-}+\mathrm{H}_{2} \mathrm{O}$ (Reeburgh 1976), and it is mediated by a consortium of sulfate-reducing bacteria and archea (Boetius et al 2000; Orphan et al 2001).

AOM can effectively remove methane from marine sediments before it reaches the sedimentwater interface, and it may consume $25-94 \mathrm{Tg}$ of methane in marine sediments each year, and the amount is between $5 \%$ and $20 \%$ of the global flux of methane to the atmosphere (Reeburgh and Alperin 1988). Hence, AOM plays a significant role in the global budgets of methane and the emission of methane into the atmosphere, where $\mathrm{CH}_{4}$ acts as a strong greenhouse gas. Furthermore, methane is oxidized with concurrent sulfate reduction during $\mathrm{AOM}$, producing inorganic carbon and volatile sulfur, and in this way it affects the biogeochemical cycle of carbon and sulfur in marine sediments (Hensen et al 2003; Jørgensen et al 2004; Moore et al 2004).

AOM could leave a distinctive imprint on the sedimentary geochemical record as revealed by the slope changes in methane and sulfate concentration profiles (e.g., Reeburgh 1976; Niewöhner et al 1998), the $\delta^{13} \mathrm{C}-\Sigma \mathrm{CO}_{2}$ minima due to the special isotope composition of methane (Blair and Aller 1995; Martens et al 1999; Tsunogai et al 2002), and the peaks of in situ AOM and sulfate reduction rates measured at the same depth (Devol 1983; Iversen and Jørgensen 1985; Treude et al 2005).

The portion of total sulfate reduction fuelled by methane oxidation varies among locations. Numerous studies have demonstrated the importance of AOM in the consumption of sulfate in marine sediments (Devol 1983; Iversen and Jørgensen 1985; Niewöhner et al 1998; Treude et al 2005). For Saanich Inlet sediments, 23-40\% of the downward sulfate fluxes were attributed to AOM according to a coupled reaction diffusion model (Devol and Anderson 1984). From interstitial flux calculations, approximately $50 \%$ of the downward sulfate fluxes at Cariaco Trench station could be accounted for AOM (Reeburgh 1976). Iversen and Jørgensen (1985) reported that $61-89 \%$ of the downward sulfate fluxes consumed by AOM at the base of sulfate reduction zone for the Kattegat and Skagerrak sediments using direct rate measurements with radiotracer labeled method. Thus, AOM needs to be investigated throughout the productive marine regions worldwide, from littoral to bathyal depths, to enhance the understanding of this complex controlled process and to evaluate its quantitative importance. However, investigations on global AOM are still incomplete (especially

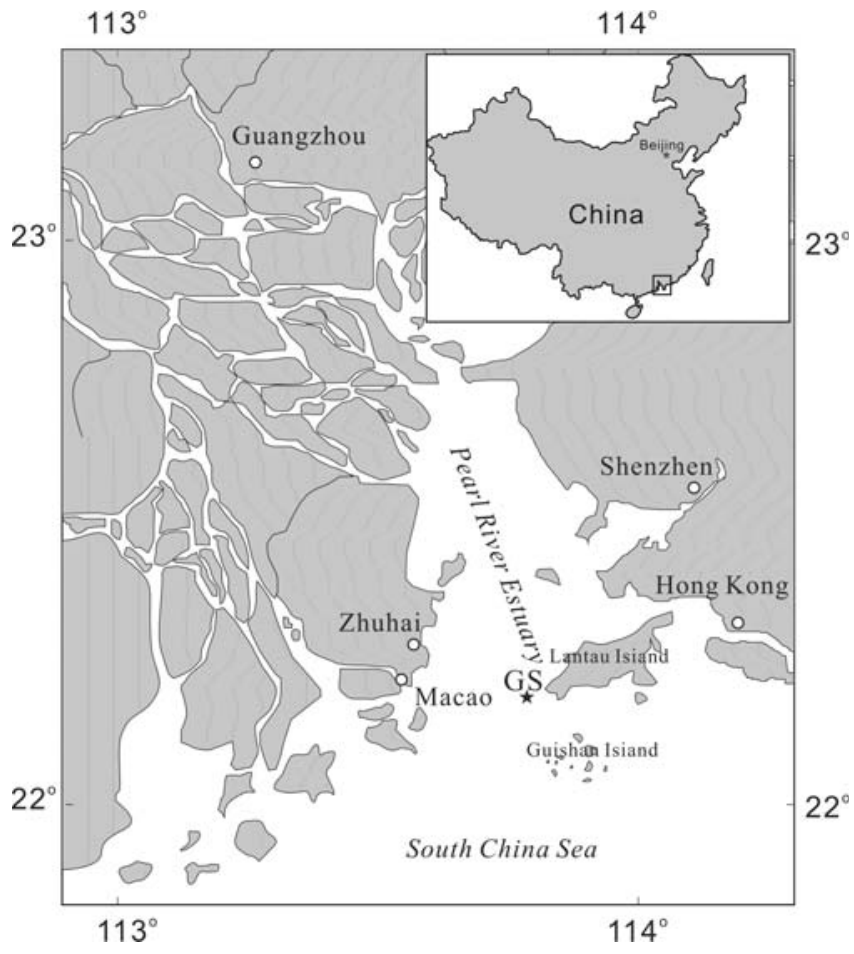

Figure 1. Map of the Pearl River Estuary, South China Sea showing the location of the sampling station GS. The inset shows a large-scale map of China with a small box marking the region expanded in the main map.

from Asian regions) at the present time. Thus, neither is much known about the magnitude and the control mechanisms that drive AOM in the different marine sediments nor how important it is concerning the global budgets of $\mathrm{C}$ and $\mathrm{S}$.

In this study, one marine sediment core from Pearl River Estuary, South China Sea was sampled. We analyzed the pore-water profiles of $\mathrm{CH}_{4}, \mathrm{SO}_{4}^{2-}$, $\Sigma \mathrm{CO}_{2}, \mathrm{pH}$ and the carbon isotope of the $\mathrm{CH}_{4}$ and $\Sigma \mathrm{CO}_{2}$, identified the process of AOM, and examined AOM's role in the consumption of sulfate and the production of $\mathrm{\Sigma CO}_{2}$ in this area.

\section{Material and methods}

\subsection{Sampling sites}

Guishan Island is situated in Wanshan district, Zhuhai city, Guangdong province. The island is 17 nautical miles from Macao and Xiangzhou to the west and three nautical miles from Lantau Island in Hong Kong to the north, forming an arc as a natural sea gate to the mouth of the Pearl River Estuary, South China Sea (figure 1).

During an investigation cruise on the Haijian 83 in the South China Sea, on 15 March 2006, a sediment gravity core (labeled as GS) was recovered from the shallow water station (at a water depth 
of $27 \mathrm{~m}$ ) near the Guishan Island. At the sampling site, the temperature of the surface and bottom water is $25.4^{\circ} \mathrm{C}$ and $15.0^{\circ} \mathrm{C}$, respectively; the salinity of the bottom water is $25.9 \%$. This sediment core mainly consists of silt clay, and the color changes from gray for the upper $12 \mathrm{~cm}$ sediments to black at the bottom. An odorous smell of $\mathrm{H}_{2} \mathrm{~S}$ was detected from $50 \mathrm{~cm}$ and below. Furthermore, the bottom water is anoxic as dissolved oxygen can be rapidly depleted by both chemical and biologic processes (Peng and Chen 1994; Jia and Peng 2003; Dai et al 2006; $\mathrm{Hu}$ et al 2006).

\subsection{Sampling methods}

Sediment samples were collected from the gravity core GS (ID $7.4 \mathrm{~cm}$, length $4 \mathrm{~m}$ ). The core barrel contained two rows of predrilled $1 \mathrm{~cm}$ ID holes so that subsamples could be taken at every $4 \mathrm{~cm}$ interval. The holes were covered with plastic tape on both, inside and outside of the core barrel, and upon retrieval of the core, the tape was carefully removed. Two replicate sediment samples of $3 \mathrm{ml}$ were taken with $5 \mathrm{ml}$ plastic syringes for methane analysis and porosity determination, respectively. The sediment sample for methane analysis was placed into a $25 \mathrm{ml}$ anaerobic glass serum vial (Bellco Company, America) filled with $6 \mathrm{ml} 1 \mathrm{M} \mathrm{NaOH}$. The vial was immediately closed using a blue butyl rubber stopper and sealed with an aluminum crimp. For pore-water sampling, the sediment core was cut into $4 \mathrm{~cm}$ slices. Within $12 \mathrm{~h}$ after the sampling, pore-water was centrifuged $(5000 \mathrm{n} / \mathrm{min})$ for $15 \mathrm{~min}$ at low temperature and filtered through cellulose acetate film $(\varphi=0.45 \mu \mathrm{m})$ in a syringe. All sediment samples were purged with $\mathrm{N}_{2}$ gas for $1 \mathrm{~min}$ and stored at $4^{\circ} \mathrm{C}$ for further measurement.

\subsection{Analytical procedures}

\subsubsection{Porosity calculation, elemental and isotopic analysis of organic matter}

Porosity is defined and calculated as the volume fraction of water in the wet sediment. The water volume is determined as the difference of sediment sample weight before and after drying at $105^{\circ} \mathrm{C}$ for five hours. Since water has a density of $1 \mathrm{~g} / \mathrm{ml}$, its volume is numerically the same as its weight.

Total organic carbon (TOC) and total nitrogen (TN) were measured using a Vario CE EA1112 C/N/S analyzer. Sediment sample of $2 \mathrm{~g}$ was freezedried, homogenized by gentle grinding in an agate mortar, treated with $1 \mathrm{M} \mathrm{HCl}$ to remove inorganic carbon, rinsed thrice with deionized water to remove salts, and dried at $60^{\circ} \mathrm{C}$. Samples were analyzed three times, and the mean values were reported here. Relative precision was estimated at $\pm 3.0 \%$ for TOC and $\pm 5.0 \%$ for $\mathrm{TN}$.

Samples for $\delta^{13} \mathrm{C}$ analysis were placed in the CE EA1112 C/N/S Analyzer and burned at $960^{\circ} \mathrm{C}$ in a combustion tube under an $\mathrm{O}_{2}$ atmosphere. Combustion gases were swept through a reduction column by a stream of inert $\mathrm{He}$ gas and passed into a gas chromatography where $\mathrm{CO}_{2}$, still in the He stream, was separated from other gases. The gas stream then entered a DELTAplusXL mass spectrometer, and the $\mathrm{CO}_{2}$ gas was analyzed and compared to NBS-22 reference gas. The internal gas standard carbon isotope ratios in sediment organic matter are expressed in conventional delta $(\delta)$ notation, the per mil $(\%)$ deviation from the standard Pee Dee Belemnite (PDB).

\subsubsection{Methane, sulfate and dissolved inorganic matter $\left(\mathrm{\Sigma CO}_{2}\right)$}

The level of methane in pore-water was determined according to Jørgensen et al (2001). The vial filled with sediment samples was shaken thoroughly to equilibrate the pore-water methane between aqueous and gaseous phases. A gas sample of $0.5 \mathrm{ml}$ was injected into a gas chromatograph (Agilent 6820, America). The GC was equipped with a flame ionization detector $\left(300^{\circ} \mathrm{C}\right)$ and a packed Porapak-Q column. The carrier gas was $\mathrm{N}_{2}$ gas $(99.999 \%)$ with high purity at a flow rate $30 \mathrm{ml} / \mathrm{min}$. Standards of $1.030 \%$ and $0.105 \%$ methane in helium were prepared. Duplicate samples were measured with a precision of $\pm 3.0 \%$. The methane concentration was recalculated to $\mu \mathrm{mol}$ per ml porewater using the analyzed sediment volume and the independently determined porosity.

The pore-water sulfate concentration was determined by an ion chromatogram (DX-600, America) equipped with conductivity detector and IonPac AS19 $(4 \times 250 \mathrm{~mm})$ column. The eluent was $9 \mathrm{mM} \mathrm{Na}_{2} \mathrm{CO}_{3}$ at a flow rate $1.0 \mathrm{ml} / \mathrm{min}$. The precision of the measurement was $\pm 0.5 \%$.

For $\Sigma \mathrm{CO}_{2}$ analyses, $1.0 \mathrm{ml} 5 \mathrm{M} \mathrm{H}_{2} \mathrm{SO}_{4}$ was placed in a $15 \mathrm{ml}$ anaerobic vial, and sealed with a rubber septum. The septum was pierced with a needle connected to a vacuum system and evacuated. Approximately $3.0 \mathrm{ml}$ of pore-water was immediately added to the vial. After several minutes, reaction of pore-water with $\mathrm{H}_{2} \mathrm{SO}_{4}$ causes complete evolution of $\Sigma \mathrm{CO}_{2}$ to $\mathrm{CO}_{2}$ gas in the headspace of the vial. Gas sample of $0.5 \mathrm{ml}$ was injected into a gas chromatograph (Agilent 6820, USA). The GC was equipped with a thermal conductivity detector $\left(300^{\circ} \mathrm{C}\right)$ and a packed $5 \mathrm{~A}$ molecule sieve column, with an analytical precision of $3.0-5.0 \%$.

Pore water $\mathrm{pH}$ was determined with an ionselective Ross combination electrode (Orion). The precision of $\mathrm{pH}$ measurements was $\pm 0.05 \mathrm{pH}$ units. 


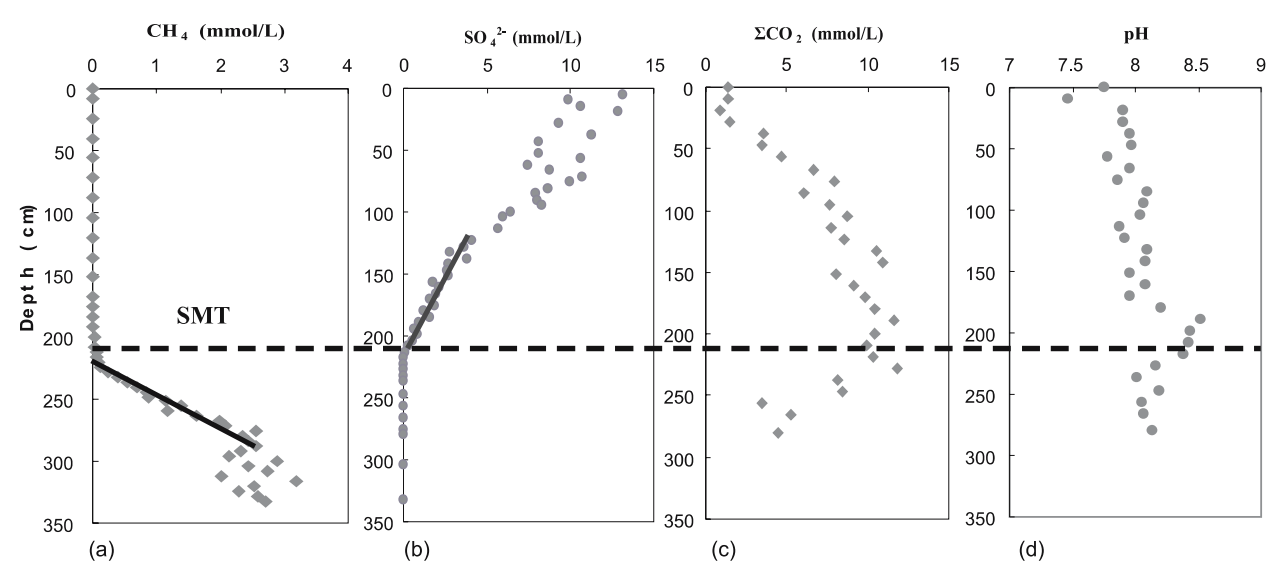

Figure 2. Pore water profiles of (a) methane, (b) sulfate, (c) total dissolved carbon dioxide concentrations $\left(\mathrm{CO}_{2}\right)$ and (d) $\mathrm{pH}$ (the hatched bar marks the sulfate-methane transition zone, and the gradients used for diffusive flux calculation are indicated by the solid lines).

2.3.3 Stable carbon isotopes of $\mathrm{\Sigma CO}_{2}$ and $\mathrm{CH}_{4}$ $\left({ }^{13} \mathrm{C}-\Sigma \mathrm{CO}_{2}\right.$ and $\left.\delta^{13} \mathrm{C}^{-} \mathrm{CH}_{4}\right)$

Samples for $\delta^{13} \mathrm{C}-\Sigma \mathrm{CO}_{2}$ analysis were acidified in the storage vial and bubbled with helium to remove $\mathrm{CO}_{2}$. Methane stable isotope samples were stripped from the sealed vials by ultrasonic degassing in water to release the methane gas to the headspace. The $\mathrm{CO}_{2}$ and methane gas stream passed through a liquid nitrogen trap to eliminate the water in the gas samples, and then was injected into Isochrom II Isotope Ratio Mass Spectrometers (IRMS) equipped with Poraplot $Q$ $(30 \mathrm{~m} \times 0.32 \mathrm{~mm})$ capillary column, where helium served as the carrier gas. The oven temperature program was as follows: the initial temperature was held at $50^{\circ} \mathrm{C}$ for $2 \mathrm{~min}$, then raised to $180^{\circ} \mathrm{C}$ at $25^{\circ} \mathrm{C} / \mathrm{min}$ and held for $8 \mathrm{~min}$. Repeated analyses for each sample were made and the precision of the measurement was $\pm 0.5 \%$. The reference standard for the carbon isotope composition was Peedee Belemnite (PDB) and the $\delta$ notation was used for describing carbon stable isotope ratios in the equation listed as follows:

$$
\delta(\%)=\left[\left(\frac{R_{\text {sample }}}{R_{\text {standard }}}\right)-1\right] \times 1000
$$

where $R$ is the ratio of heavy to light isotope in the sample or the reference standard.

\section{Results and discussion}

\subsection{Pore-water profiles of methane, sulfate, $\mathrm{\Sigma CO}_{2}$ concentration and $\mathrm{pH}$}

Figure 2 shows pore-water profiles of methane, sulfate, $\Sigma \mathrm{CO}_{2}$ concentration and $\mathrm{pH}$. The methane concentration is very low $(<10 \mu \mathrm{mol} / \mathrm{L})$ in the upper part of the sediment core, it has a steep increase at a sediment depth of $210 \mathrm{~cm}$, and it reaches $2.55 \mathrm{mmol} / \mathrm{L}$ at $276 \mathrm{~cm}$. Below this depth, the methane concentration stays relatively stable with minor fluctuation (figure 2a). This may be explained by the relatively slow sampling process. During the sampling, pore-water samples were exposed to diminished pressure, methane concentration exceeded atmospheric saturation levels, and this could cause methane loss. Thus methane concentrations measured at greater depths are not reliable (Niewöhner et al 1998), and a better and faster sampling technique is needed. The profile of sulfate concentration appears to be opposite of the one of methane concentration (figure $2 \mathrm{~b}$ ). The sulfate concentration at the top of the sediment core is at the maximum of $13.17 \mathrm{mmol} / \mathrm{L}$, and then it decreases with increasing depth till total depletion at $214 \mathrm{~cm}$. This depth of total sulfate depletion was identical in that of steep increase in methane concentration, thus sharply defining sulfate-methane transition (SMT).

The sulfate profile at the GS station shows linear gradients $\left(r^{2}=0.9252\right)$ from the initial decrease down to the depth of total depletion. However, under the assumption of organic matter degradation by sulfate reduction, convex-upward shapes of interstitial sulfate concentration profiles should be expected from theoretical diagenetic models (Berner 1980). This disagreement between predicted and measured sulfate profiles has been noticed by Jørgensen (1978). Linear sulfate profiles were also observed in sediments at Kattegat and Skagerrak (Iversen and Jørgensen 1985), Sannich Inlet (Devol 1983) and Long island (Martens and Berner 1977), and they were interpreted as evidence of sulfate reduction via AOM at the base of the sulfate reduction zone. Devol and Anderson 

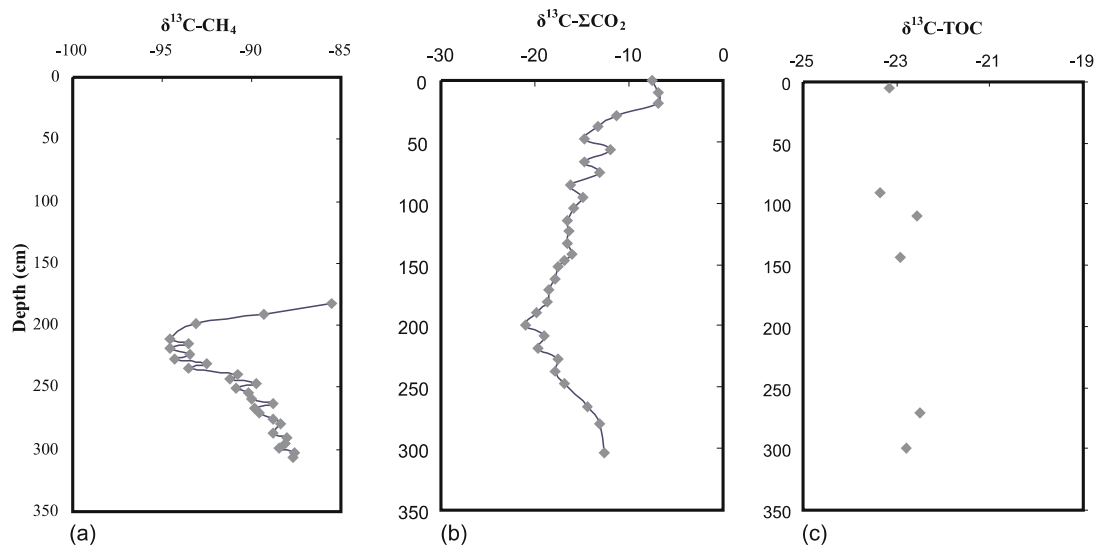

Figure 3. Depth profiles of (a) $\delta^{13} \mathrm{C}-\mathrm{CH}_{4},(\mathbf{b}) \delta^{13} \mathrm{C}-\Sigma \mathrm{CO}_{2}$ and (c) $\delta^{13} \mathrm{C}-\mathrm{TOC}$.

(1984) pointed out that the decrease in the convex curvature of sulfate gradient could increase the sulfate gradient at depth, which in turn would result in an increased downward flux of sulfate. Thus, if a significant amount of sulfate was required for AOM at depth, these 'linear' sulfate profiles would be expected. Jørgensen et al (2001) concluded that an enhanced sulfate reduction within SMT leads to linear sulfate profiles, which further indicate the occurrence of a large methane source penetrating up from below.

The depth distribution of sulfate concentrations will influence the profile of methane in sediment pore-water. Generally, biogenic methane is controlled by the process of methane production via the two most common pathways, i.e., $\mathrm{CO}_{2}$-reduction $\left(\mathrm{CO}_{2}+4 \mathrm{H}_{2} \rightarrow \mathrm{CH}_{4}+2 \mathrm{H}_{2} \mathrm{O}\right)$ and acetate dissimilation $\left(2 \mathrm{CH}_{3} \mathrm{COOH} \rightarrow \mathrm{CH}_{4}+\mathrm{CO}_{2}\right)$ (Whiticar et al 1986). In most environments including marine sediments, sulfate-reducing bacteria competes with methanogenic archaea for available electron donors such as acetate, $\mathrm{H}_{2}$, and other low-molecular weight organic compounds, which constrains the methane-producing process and thus leads to low methane concentration in the sulfate reduction zone (Sansone and Martens 1982). Once a sufficient amount of sulfate is removed from pore-water, methanogenesis would begin and result in higher concentrations of dissolved methane in the methane-producing zone. However, the upward diffusing methane will be consumed rapidly due to the process of AOM, and thereby the methane concentration gradient increases sharply near the base of the sulfate reduction zone.

The occurrence of AOM in the sediments can be further confirmed by the profiles for $\Sigma \mathrm{CO}_{2}$ concentrations and $\mathrm{pH}$ (figure 2c, d). The $\Sigma \mathrm{CO}_{2}$ concentrations increase from $1.39 \mathrm{mmol} / \mathrm{L}$ at the sediment surface to the maximal value within the SMT zone. Below this zone, the $\Sigma \mathrm{CO}_{2}$ concentrations decrease with depth. The $\mathrm{pH}$ values are also elevated and a major $\mathrm{pH}$ peak (8.52) is located within the SMT. This can be explained by saying that $\Sigma \mathrm{CO}_{2}$ added to the pore-water by $\mathrm{AOM}$, leading to an increase in $\Sigma \mathrm{CO}_{2}$ concentration and consequently to an increase in $\mathrm{pH}$ due to pore-water enrichment in $\mathrm{CO}_{3}^{2-}$ relative to $\mathrm{HCO}_{3}^{-}$ (Treude et al 2005).

\subsection{Pore water profiles of $\delta^{13} \mathrm{C}-\Sigma \mathrm{CO} \mathrm{O}_{2}$ and $\delta^{13} \mathrm{C}-\mathrm{CH}_{4}$}

The depth distribution of stable carbon isotope ratios of $\mathrm{CH}_{4}$ and $\Sigma \mathrm{CO}_{2}$ is shown in figure 3 . The $\delta^{13} \mathrm{C}-\Sigma \mathrm{CO}_{2}$ profile has a convex shape with a minimum value of $-20.91 \%$ at the depth of SMT. Below the depth, the carbon isotope of $\Sigma \mathrm{CO}_{2}$ becomes heavier with the increasing depth (figure 3a). The depth distribution of $\delta^{13} \mathrm{C}-\mathrm{CH}_{4}$ is overall very similar to that of $\delta^{13} \mathrm{C}-\Sigma \mathrm{CO}_{2}$. In the methane-producing zone, ${ }^{13} \mathrm{C}-\mathrm{CH}_{4}$ tends to be more negative with the decreasing depth. Within the SMT zone, however, the $\delta^{13} \mathrm{C}-\mathrm{CH}_{4}$ profile is opposite of that in the methane-producing zone: $\delta^{13} \mathrm{C}-\mathrm{CH}_{4}$ increases from $-94.55 \%$ to $-85.56 \%$, from $210 \mathrm{~cm}$ to $184 \mathrm{~cm}$ (figure 3b).

The increase in $\delta^{13} \mathrm{C}-\mathrm{CH}_{4}$ at a depth of below $210 \mathrm{~cm}$ can be explained by a concurrent increase in $\delta^{13} \mathrm{C}-\Sigma \mathrm{CO}_{2}$ values. The $\delta^{13} \mathrm{C}-\mathrm{CH}_{4}$ values exhibit a relatively constant offset from the corresponding $\Sigma \mathrm{CO}_{2}$ values and this is because methane is derived from an increasingly heavier $\Sigma \mathrm{CO}_{2}$ pool (Blair 1998; Martens et al 1999). However, the carbon isotope composition of methane may vary with oxidation of the upward diffusing methane. According to the Raleigh distillation effect, ${ }^{12} \mathrm{CH}_{4}$ is oxidized faster than ${ }^{13} \mathrm{CH}_{4}$, and this causes the residual methane $\delta^{13} \mathrm{C}$ enrichment and $\delta^{13} \mathrm{C}-\Sigma \mathrm{CO}_{2}$ minimum (Whiticar et al 1986; Burns 1998; Martens et al 1999). Alperin et al (1988) reported that the value of $\delta^{13} \mathrm{C}-\Sigma \mathrm{CO}_{2}$ resulting from $\mathrm{AOM}$ 
was generally lower than $-20 \%$ and the residual methane became heavier by $9 \%$ in $\delta^{13} \mathrm{C}$ on account of carbon isotope fractionation. In general, the $\delta^{13} \mathrm{C}-\Sigma \mathrm{CO}_{2}$ difference in pore-water is mainly affected by the carbon isotope compositions of its ancestors. In this study area, the dissolved inorganic carbon $\left(\Sigma \mathrm{CO}_{2}\right)$ produced by $\mathrm{AOM}$ is depleted in $\delta^{13} \mathrm{C}$ relative to that derived from the degradation of sedimentary organic matter simply because the $\delta^{13} \mathrm{C}-\mathrm{CH}_{4}$ ranges between $-87.60 \%$ and $94.55 \%$, but the sedimentary organic matter carbon isotope varies from $-22.51 \%$ to $-23.39 \%$ (figure 3c). Thus, the very low $\delta^{13} \mathrm{C}-\mathrm{CH}_{4}$ value will yield lower $\delta^{13} \mathrm{C}-\Sigma \mathrm{CO}_{2}$ values correspondingly. Furthermore, carbonate precipitation can influence the $\delta^{13} \mathrm{C}$ value of $\Sigma \mathrm{CO}_{2}$. If carbonate precipitates prior to, or during methanogenesis, the $\Sigma \mathrm{CO}_{2}$ pool would be reduced in size and the $\Sigma \mathrm{CO}_{2}$ generating via methanogenesis would be diluted. Therefore, the $\Sigma \mathrm{CO}_{2}$ would be enriched in ${ }^{13} \mathrm{C}$ relative to that from non-carbonate precipitated sediments (Blair 1998). However, the average measured pH for the station was found to vary between 7.46 and 8.52. With such $\mathrm{pH}$ values, precipitation of $\mathrm{CO}_{3}^{2-}$ species should not occur until the $\Sigma \mathrm{CO}_{2}$ concentration becomes $\geq 18.40 \mathrm{mM}$. Since the highest $\Sigma \mathrm{CO}_{2}$ concentration measured at these sites is $11.82 \mathrm{mM}$, the precipitation reactions will not be considered in this study.

\subsection{AOM mediated consumption of sulfate and production of $\mathrm{\Sigma CO}_{2}$}

Diffusive fluxes of methane and sulfate were calculated from linear pore water concentration gradients according to Fick's first law assuming steady state conditions (e.g., Berner 1980):

$$
J=-\varphi \cdot D_{s} \frac{d c}{d x}
$$

where $J$ is the diffusive flux $\left(\mathrm{mmol} \mathrm{m} \mathrm{m}^{-2} \cdot \mathrm{a}^{-1}\right), \varphi$ is the porosity, $D_{s}$ is the sediment diffusion coefficient $\left(\mathrm{m}^{2} \cdot \mathrm{a}^{-1}\right), c$ is the concentration of either sulfate or methane $\left(\mathrm{mmol} \cdot \mathrm{L}^{-1}\right)$, and $x$ is the depth (m). The steepest concentration gradient in the SMT was used in the calculation. The gradients are marked by solid lines in the concentration profiles of methane and sulfate (figure 2a, b). Sediment diffusion coefficients, $D_{s}$, of methane and sulfate were calculated according to Iversen and Jørgensen (1985) from the measured porosities:

$$
D_{s}=\frac{D_{0}}{1+n(1-\varphi)}
$$

using $n=3$ for clay-silt sediments.
At the in situ temperature of $15^{\circ} \mathrm{C}$, the molecular diffusion coefficients, $D_{0}$, in seawater are: $D_{0}$ methane $=1.4 \times 10^{-5} \mathrm{~cm}^{2} \cdot \mathrm{s}^{-1}, D_{0}$ sulfate $=$ $1.1 \times 10^{-5} \mathrm{~cm}^{2} \cdot \mathrm{s}^{-1}$ (Boudreau 1997). Based on the assumption and calculation mentioned above, the methane and sulfate diffusive fluxes were $2.926 \times 10^{-6} \mathrm{mmol} \cdot \mathrm{cm}^{-2} \mathrm{~s}^{-1}$ and $4.990 \times$ $10^{-6} \mathrm{mmol} \cdot \mathrm{cm}^{-2} \mathrm{~s}^{-1}$, respectively.

If AOM takes place in the sediments, all upward methane diffusing into the bottom of sulfate reduction zone is consumed in 1:1 molar ratio (Nauhaus et al 2002). Thus the portion of sulfate reduction occurring via AOM was calculated to be $2.926 \times 10^{-6} / 4.99 \times 10^{-6}=58.6 \%$.

The percentage of $\Sigma \mathrm{CO}_{2}$ added to pore-water from each source cannot, however, be directly equated to the percentage of sulfate reduced by each process. The sulfur to carbon stoichiometries of the reaction between sulfate and sedimentary organic carbon, as described by the following equation:

$$
\mathrm{SO}_{4}^{2-}+2 \mathrm{CH}_{2} \mathrm{O}=2 \mathrm{HCO}_{3}^{-}+\mathrm{H}_{2} \mathrm{~S},
$$

and the net reaction between sulfate and methane, as described by the following equation:

$$
\mathrm{SO}_{4}^{2-}+\mathrm{CH}_{4}=\mathrm{HCO}_{3}^{-}+\mathrm{HS}^{-}+\mathrm{H}_{2} \mathrm{O}
$$

are 1:2 and 1:1, respectively. Thus, the percentage of sulfate reduction by methane oxidation, $Y$, is: $X=Y /(2-Y)$, where $X$ is the fraction of $\Sigma \mathrm{CO}_{2}$ produced by methane oxidation. Therefore, the percentage of $\Sigma \mathrm{CO}_{2}$ in the pore-water derived from $\mathrm{AOM}$ is $41.4 \%$.

\subsection{Possible mechanism of sulfate reduction via methane oxidation}

As shown in figure 4, the TOC and TN near the sediment surface are higher than those in the deeper sediments, and they display an obviously decreasing trend with increasing depth in the upper $132 \mathrm{~cm}$. However, below this depth, the TOC and TN show no noticeable difference with the depth change. The distribution of TOC and TN content reflects high sedimentation rate in the sediments at Guishan Island, and thereby high input of sedimentary organic matter may limit the time for initial organic matter degradation in the surface sediments. Thus, a significant fraction of the initially deposited organic material escaped degradation in the surface sediments and was buried (Treude et al 2005). This buried material can 


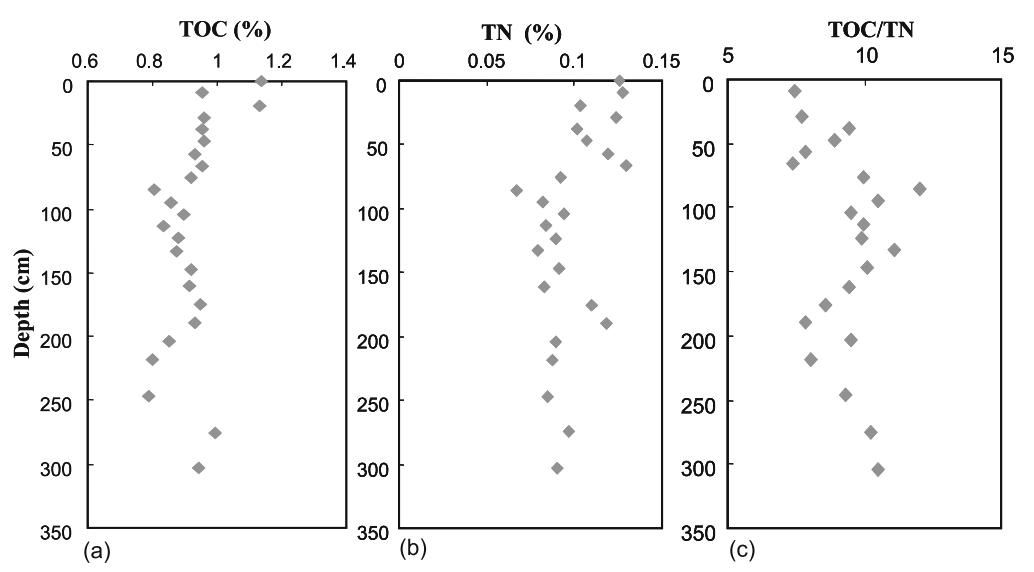

Figure 4. Depth profiles of (a) TOC, (b) TN and (c) TOC/TN.

be supplied as carbon source for the process of methanogenesis, causing an increase of methane concentration and methane diffusion fluxes and thus providing the necessary condition for AOM.

The depth of SMT in the sediments of the GS station is shallower than SMTs in abyssal sediments such as in the Chile continental margin (Treude et al 2005), West African margin (Moore et al 2004) and Amazon Fan (Burns 1998), but is deeper than those in Skan Bay (Reeburgh 1980), Saanich Inlet (Devol 1983; Devol and Anderson 1984) and Eckernförde Bay (Martens et al 1998, 1999). The depths of SMT are controlled by the amount of sedimentary organic matter in the sediments, and the great amount of organic material is favorable for rapid depletion of sulfate via sedimentary organic matter degradation. Additionally, great amounts of organic material in the sediments can also increase the methane fluxes in the SMT, and thus result in a portion of sulfate consumption via AOM. In these cases, the SMT will be shifted towards the sediment surface.

The occurrence of AOM depends upon the availability of labile algal-derived organic matter. When organic matter is dominated by low lignin kelp (marine derived), sulfate will be prone to reduction via the process of oxidization of sedimentary organic matter. Thus, the percentage of sulfate reduction by AOM is relatively small. However, when the organic matter has a large refractory terrestrial component, methane would become a relatively more important electron donor and the portion of sulfate reduction via AOM would be larger (Devol and Anderson 1984; Treude et al 2005).

The $\delta^{13} \mathrm{C}-\mathrm{TOC}$ value and $\mathrm{TOC} / \mathrm{TN}$ ratio are commonly used index to identify the origins of a sediment organic matter. Generally, the typical $\delta^{13} \mathrm{C}-\mathrm{TOC}$ values of terrestrial organic matter range from $-26 \%$ to $-28 \%$ and of marine phytoplankton from $-19 \%$ to $-22 \%$ (Fry and
Sherr 1984; Boutton 1991). In addition, land plants and algae are also diverse in their TOC/TN ratios: marine algae, due to richness in protein and absence of cellulose, typically have $\mathrm{C} / \mathrm{N}$ ratios between 4 and 10, whereas vascular land plants, due to abundance of cellulose, have $\mathrm{C} / \mathrm{N}$ ratios of 20 and greater (Meyers 1997). In this study, $\delta^{13} \mathrm{C}-\mathrm{TOC}$ value and TOC/TN ratio ranged from $-22.51 \%$ to $-23.39 \%$ and from 7.46 to 12.00 , respectively, indicating different organic matter sources for the GS sediment core. We attempted to assess the relative proportions of terrestrial and marine organic matter present in the sediments GS. The approach is based on the mixing model of Schultz and Calder (1976), which assumes $\delta^{13} \mathrm{C}-\mathrm{TOC}$ values of various terrestrial and marine end-members cited from Jia and Peng (2003) and $\mathrm{Hu}$ et al (2006). The estimated proportion of the algal-derived marine organic matter contents in the sediments GS is $48.9 \%$. The preferential degradation of labile nitrogen-rich organic matter (mainly marine-derived organic matter) in the upper sediments of GS may reduce the amount of labile algalderived organic matter that could be incorporated into the base of sulfate reduction zone. This inference is confirmed by the TN distribution profile: the TN content in the sediment surface is relatively high, and the ratio of TOC/TN increases with depth. Due to the scarcity of labile organic matter, the sulfate will in turn be consumed by AOM at the base of the sulfate reduction zone, and this reaction was mediated by an archaeal population and sulfate-reducing bacteria (Hoehler et al 1994).

\section{Conclusion}

The sulfate concentration decreases linearly with increasing depth till total depletion at $214 \mathrm{~cm}$, and this depth is identical to that of steep increase in methane concentration. This profile of methane and sulfate indicates the existence of 
SMT at the base of the sulfate reduction zone. Within the SMT, the $\delta^{13} \mathrm{C}-\mathrm{CH}_{4}$ becomes enriched, $\delta^{13} \mathrm{C}-\Sigma \mathrm{CO}_{2}$ has a minimum value of $-20.91 \%$, and the $\Sigma \mathrm{CO}_{2}$ and $\mathrm{pH}$ are elevated. These pore-water profiles render the evidence of $\mathrm{AOM}$ occurring in the GS sediment core of Guishan Island, South China Sea.

AOM can contribute to sulfate consumption and $\Sigma \mathrm{CO}_{2}$ production in sediment pore-water. Based on the calculation from diffusive model, the portion of pore-water sulfate reduction occurring via $\mathrm{AOM}$ is found to be $58.6 \%$, and the percentage of $\mathrm{CO}_{2}$ added in the pore-water by AOM is $41.4 \%$. The estimated results indicate that the process of AOM plays an important role in the carbon and sulfur cycling in the marine sediments of the Pearl River Estuary.

The process of AOM is largely controlled by the quality and quantity of the organic matter. In the GS sediment core, the estimated proportion of the algal-derived marine organic matter content is $48.9 \%$. The preferential degradation of labile nitrogen-rich organic matter (mainly marinederived organic matter) in the upper sediments of GS may reduce the amount of the labile organic matter that could be incorporated into the base of the sulfate reduction zone. Thus, a great amount of labile organic matter (mainly labile alga marinederived) is consumed via the process of sedimentary organic matter diagenesis, which results in the decrease of the labile organic matter incorporated into the base of the sulfate reduction zone. Due to the scarcity of labile organic matter, the sulfate will in turn be consumed by reaction with methane at the base of the sulfate reduction zone, and thereby $\mathrm{AOM}$ takes place.

\section{Acknowledgements}

We thank the shipboard scientists, captain, and crew of the R/V Haijian 83 for their excellent support during the South China Sea cruise in March, 2006. We thank Dr Liu Jinzhong for his assistance in analyzing the stable carbon isotopes of methane and $\mathrm{CO}_{2}$. We would also like to thank Dr Tina Treude and an anonymous reviewer for their very helpful comments on the manuscript. This research was supported by the National Basic Research Project (Grant No. G200007850), National Natural Science Foundation of China (Grant No. 40803020) and the Opening Foundation of State Key Laboratory of Marine Geology, Tongji University (Grant No. MG0807).

\section{References}

Alperin M J, Reeburgh W S and Whiticar M J 1988 Carbon and hydrogen isotope fractionation resulting from anaerobic methane oxidation; Global Biogeochemical Cycles 2 279-288.

Berner R A 1980 Early diagenesis: A theoretical approach (Princeton N.J.: Princeton University Press) 241.

Blair N 1998 The $\delta^{13} \mathrm{C}$ of biogenic methane in marine sediments: The influence of $\mathrm{C}_{\text {org }}$ deposition rate; Chemical Geology 152 139-150.

Blair N E and Aller R C 1995 Anaerobic methane oxidation on the Amazon shelf; Geochim. Cosmochim. Acta $\mathbf{5 0}$ 3707-3715.

Boetius A, Ravenschlag K, Schubert C J et al 2000 A marine microbial consortium apparently mediating anaerobic oxidation of methane; Nature $407623-625$.

Boudreau B P 1997 Diagentic models and their implementation: Modeling transport and reaction in acquatic sediments (Berlin, Heidelberg, New York: Springer) 414 p.

Boutton T W 1991 Stable carbon isotope ratios of natural materials: II. Atmospheric, terrestrial, marine, and freshwater environments; In: Carbon Isotopes Techniques, Coleman D C and Fry B (eds) (San Diego: Academic Press, Inc.) $173-185 \mathrm{p}$.

Burns S 1998 Carbon isotopic evidence for coupled sulfate reduction-methane oxidation in Amazon Fan sediment; Geochim. Cosmochim. Acta 62 797-804.

Dai M H, Guo X H, Zhai W D et al 2006 Oxygen depletion in the upper reach of the Pearl River estuary during a very drought winter; Marine Chemistry 102 159-169.

Devol A H 1983 Methane oxidation rates in the anaerobic sediments of Sannich Inlet; Limnol. Oceanogr. 28 $738-742$

Devol A H and Anderson J J 1984 A model for coupled sulfate reduction and methane oxidation in the sediments of Saanich Inlet; Geochim. Cosmochim. Acta $\mathbf{4 8}$ 993-1004.

Froelich P N et al 1979 Early oxidation of organic matter in pelagic sediments of the eastern equatorial Atlanticsuboxic diagenesis; Geochim. Cosmochim. Acta $\mathbf{4 3}$ 1075-1080.

Fry B and Sherr E B $1984 \delta^{13} \mathrm{C}$ measurements as indicators of carbon flow in arine and freshwater ecosystems; Contrib. Marine Sci. 27 13-47.

Hensen C H, Zabel M, Pfeier K et al 2003 Control of sulfate pore-water profiles by sedimentary events and the significance of anaerobic oxidation of methane for burial of sulfur in marine sediments; Geochim. Cosmochim. Acta 67 2631-2647.

Hoehler T M, Alperin M J, Albert D B et al 1994 Field and laboratory studies of methane oxidation in an anoxic marine sediment: Evidence for a methanogenic-sulfate reducer consortium; Global Biogeochemical Cycles $\mathbf{8}$ 451-463.

Hu J F, Peng P A, Jia G D et al 2006 Distribution and sources of organic carbon, nitrogen and their isotopes in sediments of the subtropical Pearl River estuary and adjacent shelf, Southern China; Marine Chemistry 98 $274-285$.

Iversen N and Jørgensen B B 1985 Anaerobic methane oxidation rates at the sulfate-methane transition in marine sediments from Kattegat and Skagerrak (Denmark); Limnol. Oceanogr. 30 944-955.

Jia G D and Peng P A 2003 Temporal and spatial variations in signatures of sedimentary organic matter in Lingding Bay (Pearl estuary), southern China; Marine Chemistry $8247-54$.

Jørgensen B B 1978 A comparison of methods for the quantification of bacterial sulfate reduction in coastal marine sediments. II: Calculation from mathematical models; Geomicrobiological Journal 1 11-28. 
Jørgensen B B, Bottcher M E, Luschen H et al 2004 Anaerobic methane oxidation and a deep $\mathrm{H}_{2} \mathrm{~S}$ sink generate isotopically heavy sulfides in Black Sea sediments; Geochim. Cosmochim. Acta 68 2095-2118.

Jørgensen B B, Weber A and Zopfi J 2001 Sulfate reduction and anaerobic oxidation in Black Sea sediments; DeepSea Res. I 48 2097-2120.

Lelieveld J, Crutzen P J and Dentener F J 1998 Changing concentration, lifetime and climate forcing of atmospheric methane; Tellus 50 128-150.

Martens C S and Berner R A 1977 Interstitial water chemistry of anoxic Long island sediments (I): Dissolved gases; Limnol. Oceanogr. 22 10-25.

Martens C S, Albert D B and Alperin M J 1998 Biogeochemical processes controlling methane in gassy coastal sediments - Part II. A model coupling organic matter flux to gas production, oxidation and transport; Cont. Shelf Res. 18 1741-1770.

Martens C S, Albert D B and Alperin M J 1999 Stable isotope tracing of anaerobic methane oxidation in the gassy sediment of Eckernforde Bay, German Baltic Sea; $\mathrm{Am}$. J. Sci. 299 589-610.

Meyers P A 1997 Organic geochemical proxies of paleoceanographic, paleolimnologic, and paleoclimatic processes; Organic Geochemistry 27 213-250.

Moore T S, Murray R W, Kurtz A C et al 2004 Anaerobic methane oxidation and the formation of dolomite; Earth Planet. Sci. Lett. 229 141-154.

Nauhaus K, Boetius A, Krüger M et al 2002 In vitro demonstration of anaerobic oxidation of methane coupled to sulphate reduction in sediment from a marine gas hydrate area; Environmental Microbiology 4 296-305.

Niewöhner C, Hensen C, Kasten S et al 1998 Deep sulfate reduction completely mediated by anaerobic methane oxidation in sediments of the upwelling area off Namibia; Geochim. Cosmochim. Acta 62 455-464.

Orphan V J, House C H, Hinrinchs K et al 2001 Methaneconsuming archaea revealed by directly coupled isotopic and phylogenetic analysis; Science 293 484-487.

Peng Y H and Chen L D 1994 The relationships between dissolved oxygen and nitrate, Chla and nitrate, phosphate; J. Oceanogr. 16 136-140 (in Chinese).

Reeburgh W S 1976 Methane consumption in Cariaco Trench waters and sediments; Earth Planet. Sci. Lett. 28 337-344.

Reeburgh W S 1980 Anaerobic methane oxidation: Rate depth distributions in skay Bay sediments. Earth Planet. Sci. Lett. 47 345-352.

Reeburgh W S and Alperin M J 1988 Studies on anaerobic methane oxidation; SCOPE/UNEP 66 367-375.

Sansone F J and Martens C S 1982 Volatile fatty acid cycling in organic-rich marine sediments; Geochim. Cosmochim. Acta 46 1575-1589.

Schultz D and Calder J A 1976 Organic carbon ${ }^{13} \mathrm{C} /{ }^{12} \mathrm{C}$ variations in estuarine sediments; Geochim. Cosmochim. Acta 40 381-385.

Treude T, Niggemann J, Kallmeyer J et al 2005 Anaerobic oxidation of methane and sulfate reduction along the Chilean continental margin; Geochim. Cosmochim. Acta $692767-2779$.

Tsunogai U, Yoshida N and Gamo T 2002 Carbon isotopic evidence of methane oxidation through sulfate reduction in sediment beneath cold seep vents on the seafloor at Nankai Trough; Marine Geology 187 145-160.

Whiticar M J, Faber E and Schoell M 1986 Biogenic methane formation in marine and freshwater environments: $\mathrm{CO}_{2}$ reduction vs. acetate fermentation - isotope evidence; Geochim. Cosmochim. Acta 50 693-709. 